\title{
AHKAM AL-KHAMS DALAM DINAMIKA PEMIKIRAN HUKUM ISLAM DAN PERUBAHAN SOSIAL
}

\author{
Sahlul Fuad \\ Institut PTIQ Jakarta, DKI Jakarta, Indonesia \\ Email: sahfuad@ptiq.ac.id
}

\begin{abstract}
Abstrak
Artikel ini mengajukan pendapat bahwaAhkam al-Khams sebagai acuan penilaiaan perbuatan atau tindakan dalam Islam memiliki ketahanan terhadap dinamika pemikiran hukum Islam dan perubahan sosial. Hingga saat ini hukum Islam tetap memberlakukan lima kategori untuk menilai perilaku atau tindakan para mukallaf, yang sering disebut dengan istilahAhkam al-Khams, yaitu: Wajib, Mandub, Mubah, Makruh, dan Haram. Kelima hukum tersebut menjadi acuan untuk menilai perbuatan atau tindakan (amal) para mukallaf, baik terkait hubungan dengan Tuhan (ibadah) maupun hubungan sesama manusia (muamalah). Ketetapanketetapan hukum tersebut pada dasarnya merupakanhasil interpretasi para ulama atas wahyu, yang yang didasarkan pada pertimbangan kriteria dan kondisi tertentu. Walaupun saat ini telah terjadi perkembangan sosial dan dinamika pemikiran hukum yang sangat pesat, namun ahkam al-khmas tetap memiliki relevansi dan tidak mengalami perubahan, kecuali pergeseran status akibat perubahan penafsiran atau pengambilan hukum atas sumber hukum.
\end{abstract}

Kata Kunci: Ahkam Al-Khams, Hukum, Syariat, Perintah, Larangan.

\section{Pendahuluan}

$\mathrm{P}$ erintah dan larangan merupakan salah satu pokok persoalan penting dalam ajaran Islam, yang mendapatkan perhatian khusus para ahli ushul fiqh. Ketentuan tentang perintah dan larangan dalam Islam harus didasarkan pada sumber-sumber hukum Islam utama, yaitu al-Quran dan as-Sunnah, namun jika tidak ditemukan dari kedua sumber tersebut diperlukan al-Ijma' dan al-Qiyas sebagai ketetapan hukum.Hal ini disebabkan tidak semua hal dalam al-Quran terdapat dalil-dalil yang bersifat sangat terang sehinggga tidak dapat di-ta'wil-kan atau dipahami dalam pengertian yang lain, namun ada juga yang pengertiannya memerlukan ta'wil atau lafazhnya memiliki arti lebih dari satu. Begitu juga keragaman as-Sunnah dan pengertian yang dikandungnya. Meski demikian, umat Islam membutuhkan kepastian dan kejelasan hukum atas ketentuan-ketentuan tentang perintah dan larangan dari sumber utama tersebut, sehingga para ulama melakukan ijtihad sebagai bentuk upaya memahami maksud yang dikehendakiAllah swt dan Rasul-Nya, serta sebagai bentuk ketaatan dalam menjalankan perintah dan larangan kepada Allah dan Rasul-Nya.Dengan demikian terdapat dua sumber utama hukum dalam Islam,yakni wahyu dan penalaran manusia ('aql). Terkait kedua sumber tersebutdapat didasarkan pada sebuah hadits yang diriwayatkan Abu Dawud sebagai berikut: 


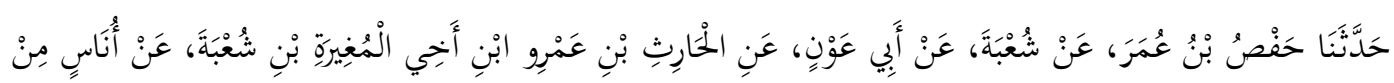

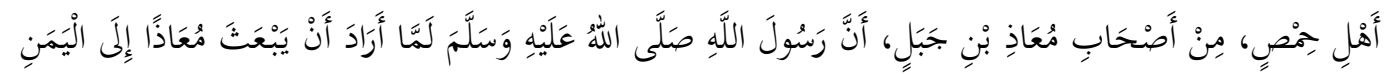

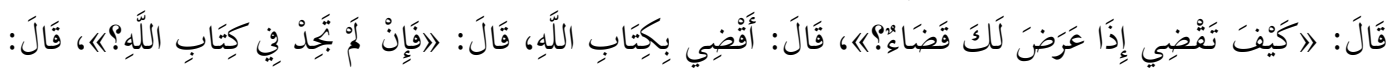

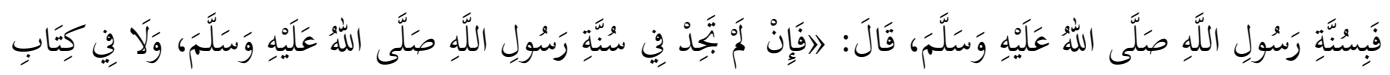

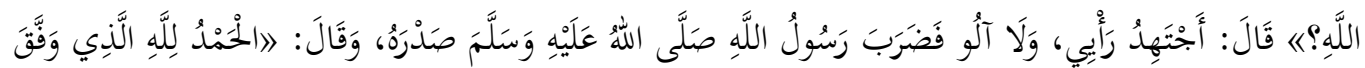

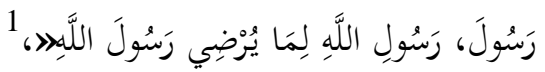

Hadits di atas menengaskan bahwa tidak semua perkara memiliki dalil atau aturan yang jelas dalam kitab al-Quran dan as-Sunnah, tetapi manusia juga diberi peluang untuk memutuskan berdasarkan pikirannya. Pendapat Muadz yang disetujui Rasulullah menunjukkan bahwa dasar utama suatu keputusan perkara agama adalah bersumber pada kitab Allah. Akan tetapi, jika di dalam kitab Allah tersebut tidak ditemui, yang dijadikan sandaran hukum adalah sunnah Rasul-Nya, dan apabila dari kedua sumber tersebut tidak ditemui seseorang dapat mengambil keputusan berdasarkan pemikiran yang mendalam. Implikasi hukum tentang ketentuan perintah dan larangan yang disampaikan Allah swt dan Rasulullah saw dalam al-Quran dan as-Sunnah dipandang berbeda menurut ahli Ushul Fiqh dan ahli Fiqh.Menurut kajianUshul Fiqh implikasinyaadalah terbentuknya hukum dalam Islam. Akan tetapi menurut Ahli Fiqh, yang disebut sebagai hukum adalah efek dari perintah atau larangannya. ${ }^{2}$ Contoh, kalimat perintah (أقم الصلوة merupakan kalimat yang mengandung keterangan tentang kewajiban shalat. Menurut ahli Ushul Fiqih ketentuan perintah mendirikan shalat tersebut merupakan hukum.

Sedangkan menurut Ahli Fiqih kewajiban shalat adalah hukum. Bagitu juga firman. Bagitu juga pada kalimat larangan (لا يسخر قوم... الى أخر menurut ahli Ushul Fiqh adalah hukum. Sedangkan yang disebut hukum oleh ahli Fiqh adalah keharaman mengolok-olok dan seterusnya. Selain perintah dan larangan tersebut, para ulama Ushul Fiqh membagi hukum menjadi dua, yaitu hukum taklifi dan hukum wadh'i. Hukum taklifi adalah berkaitan dengan pemberian beban, sedangkan hukum wadh'i berkaitan dengan sebab, syarat, atau penghalang sesuatu. Terkait hukum taklif, hampir seluruh ahli fiqh sepakat ada 5 (lima) hukum. Menurut mazhab Mu'tazilah kategori hukum dapat dibagi menjadi 2 (dua), yaitu perintah dan larangan. Sedangkan menurut Imam Hanafi mengajukan

\footnotetext{
${ }^{1}$ Abu Daud Sulaiman, Sunan Abu Daud, juz 3, Hadist nomor 3592, (Beirut: Maktabah alAshriyah ), 303

${ }^{2}$ Mukhtar Yahya dan Fatchur Rahman, Dasar-Dasar Pembinaan Hukum Fiqh Islami, (Bandung: Al-Ma'arif, 1986), 123

${ }^{3}$ Surat al-Ankabut ayat 45

${ }^{4}$ Surat al-Hujurat ayat 11
} 
7 (tujuh) kategori. Pada makalah ini hanya akan membahas lima kategori yang disepakati para ulama.

\section{Konsep Dasar Hukum Islam}

Sebelum membahas masing-masing kelima hukum, bagian ini akan terlebih dahulu akan membahas konsepsi hukum dalam Islam (hukum syar'i). Secara umum, hukum adalah ukuran, patokan, norma, dalil, rumusan dasar atau aturan yang sudah pasti. Secara bahasa, hukum adalah batasan, sehingga seseorang tidak boleh memutuskan suatu hukum kecuali dalam peradilan. ${ }^{5}$ Sebagaimana telah dijelaskan pada bagian sebelumnya, bahwa sumber hukum Islam (hukum syar'i) adalah al-Quran, as-Sunnah, Ijma', dan Qiyas, serta beberapa sumber hukum lainnya. Adapun yang diatur dalam hukum tersebut adalah segala perbuatan manusia, baik berupa tingkah laku, maupun perkataannya yang berkaitan dengan peribadatan, muamalat, dan lain-lain, selain yang berkaitan dengan akidah. Konsep Hukum Syar'i, menurut para Ahli Ushul Fiqh, mencakup tiga elemen dasar, yaitu pembuat hukum (al-hakim), perbuatan hukum (mahkum bih), dan subyek hukum (mahkum alaih). ${ }^{6}$

Para ulama sepakat bahwa satu-satunya pembuat hukum syar'i (al-hakim) adalah Allah swt. Akan tetapi, para ulama berbeda pendapat bahwa akal manusia dapat mengetahui hukum-hukum tersebut. Ada yang berpendapat bahwa akal tidak mampu memahami hukum-hukum dan sebaliknya ada yang berpendapat bahwa akal dapat memhami adanya hukum tersebut. Meski demikian, kebanyakan para ulama berpendapat bahwa pada prinsipnya, akal dapat mengetahui baikburuknya suatu perbuatan. Sedangkan yang dimaksud dengan perbuatan hukum (mahkum fih) adalah perbuatan orang-orang mukallaf yang mendapat beban hukum. Para ulama telah menyepakati bahwa yang menjadi beban hukum adalah perbuatan, bukan lainnya. Segala hal yang diperintahkan atau yang dilarang adalah berkaitan dengan perbuatan orang. Adapun yang dimaksud dengan subyek hukum (mahkum alaih) adalah orang-orang memenuhi syarat mukallaf untuk menerima beban hukum. Setidaknya ada dua syarat sebagai subyek hukum dalam Islam, yaitu: orang yang sanggup memahami ketentuan-ketentuan beban hukum dan orang yang memiliki kemampuan menerima beban hukum. ${ }^{7}$

Dari elemen-elemen dasar hukum tersebut, para ulama merumuskan bahwah yang disebut sebagai hukum syar'i adalah pernyataan-peryataan atau ketentuan-ketentuansang pembuat hukum yang berhubungan dengan tingkah laku orang-orang mukallaf, yang di dalamnya terdapat tuntutan, atau pilihan, atau

\footnotetext{
${ }^{5}$ Abu Abdullah, Syarh al-Mukhtashar li Nazhm al-Waraqat

${ }^{6}$ Aminah Mazighah, al-Manhaj al-Ijtihad 'Ind Hujjah al-Islam Abi Hamid al-Ghazaly, (Dar al-Kutub al-Ilmiyah, 2019),

${ }^{7}$ Munir Ahmad Mughal, Islamic Jurisprudence (August 2, 2000). http://dx.doi.org/10.2139/ssrn.1903980
} 
menjadikan hal sebagai sebab, syarat, atau penghalang bagi adanya hal lain. Yang disebut mukallaf atau subyek hukum dalam Islam, menurut para ulama, memiliki kriteria tertentu, antara lain: usia dan kemampuan akal. Dari segi usia orang disebut mukallaf adalah orang-orang sudah masuk kategori dewasa. Ukuran dewasa dilihat dari gejala kematangan seksual, yakni sudah memproduksi sel telur. Kemampuan akal yang dimaksud adalah dapat membedakan hal baik dan buruk, benar dan salah, serta mengerti berbagai jenis hukum atas obyek perbuatan. ${ }^{8}$ Sedangkan patokan atau ukuran yang dijadikan sebagai instrumen untuk menilai perbuatan mukallaf di bidang ibadah dan muamalah tersebut dalam Islam terdapat lima kategori, yang dikenal dengan al-Ahkam al-Khams. Kelima kategori tersebut adalah: Ijab (wajib, fardl), dianjurkan (sunnah, mandub, mustahab), boleh (mubah, jaiz, ibahah), tidak disukai (makruh), dan dilarang (haram). Selain berfungsi sebagai ukuran atau standar untuk norma hukum,Ahkam al-Khams juga dapat dijdikan untuk mengukur moral atau etik umat Islam dalam kehidupan sehari-hari. Bahkan hukum-hukum tersebut dapat dipergunakan dalam mengklafsifikasi kesehatan medis dalam menjaga tubuh manusia. Selian itu, ketentuan ini juga menjadi cara orang-orang muslim menjaga hati nuraninya agar tetap jernih.

\section{Ahkam al-Khams dan Pembagiannya}

Ahkam al-Khams merupakan istilah yang berasal dari bahasa Arab, yang berarti lima hukum. Istilah Ahkam al-Khams juga dikenal dengan nama hukum taklifi. ${ }^{9}$ Hukum taklifi merupakan tuntutan berupa ketentuan untuk dikerjakan atau ditinggalkanatau dapat berupa pilihan antara untuk dikerjakan atau ditinggalkan para mukallaf (atau orang yang berhak mendapat beban hukum). Ketentuan-ketentuan yang berisi tuntutan atau pilihan perbuatan tersebut dapat dibagi menjadi lima, yaitu jaiz, makruh, wajib, sunnah, dan haram. Masingmasing ketentuan tersebut kualitasnya beragam, ada yang tinggi dan ada yang rendah. Disebut tinggi seperti wajib dan haram, dan disebut rendah seperti makruh dan sunnah. Hal ini sangat terguntung pada penyebabnya (illat). ${ }^{10}$ Ahkam alKhams, dalam sistem hukum Islam, merupakan ajaran yang mencakup seluruh kehidupan manusia di berbagai lingkungannya, seperti kesusilaan pribadi, dalam kehidupan masyarakat, dan hukum duniawi. Ketiga hal tersebut merupakan satu kesatuan yang saling bertautan satu sama lainnya. Adapun lima macam hukum

\footnotetext{
${ }^{8}$ Muhammad Syukri Albani Nasution,Filsafat Hukum Islam,(Jakarta : Rajawali Pers,2014), 82.

${ }^{9}$ Zainuddin Ali,Hukum Islam : Pengantar Ilmu Hukum Islam di Indonesia. (Jakarta :Sinar Grafika, 2010), 54

${ }^{10}$ M. Tahir Azhary. Bunga Rampai Hukum Islam : Sebuah Tulisan. Jakarta : Ind HillCo,2003), 106.
} 
tersebut juga berlaku dalam fiqih. Berikut ini akan diuraikan masing-masing hukum tersebut beserta pembagiannya.

\section{Ijab/Fardlu}

Ijab adalah ketentuan syar'i yang menuntutagar seseorang melaksanakan perbuatan dengan keharusan yang pasti. Implikasi dari ketentuan ini disebut sebagai wajib atau fardlu. Selain istilah wajib atau fardlu juga dikenal istilah hatmun dan lazimun. Meski kebanyakan para ulama menyamakan antara wajib dan fardlu, para ulama madzhab Hanafi membedakan antara wajib dan fardlu. Sebuah tindakan yang diwajibkan dalam sumber utama tingkat pertama, yakni jelas dan definitif maka disebut sebagai fardlu, seperti perintah shalat, haji, menaati kedua orang tua, dan seterusnya. Sedangkan perintah wajib tingkat kedua disebut sebagai wajib, seperti kewajiban membaca surah al-Fatihah dalam shalat, atau untuk melakukan shalat al-witr tiga rakaat, dan sebagainya. Impikasi dari pembedaan hukum wajib dan fardlu ini adalah bahwa perbuatan fardlu multak harus dijalankan atau mengikat. Sedangkan yang wajib tidak berdampak pada rusaknya (batal) perkara yang lain. ${ }^{11}$ Hukum wajib merupakan jenis hukum yang memiliki konsekuensi pahala (reward) bagi yang menjalankan dan sanksi (punnish) bagi orang yang meninggalkan.

Ketentuan tentang perbuatan wajib dapat diketahui melalui beberapa indikator dalam dalil atau ketentuan, antara lain: ${ }^{12}$

1. Terdapat kata-kata yang menjukkan keharusan untuk dikerjakan, seperti kata "kutiba".

2. Menggunakan kata kerja perintah (fi'il amr) yang dikuatkan dengan kata-kata yang tegas, seperti adanya penguatan kata "faridlah"

3. Terdapat keterangan sanksi bagi yang tidak menjalankan kewajiban, seperti ancaman akan dimasukkan ke neraka.

Kewajiban dapat dibagi menjadi beberapa bagian dengan empat pertimbangan sebagai berikut: ${ }^{13}$

1. Pertimbangan berdasarkan kondisi waktu. Ditinjau dari kondisi waktu, kewajiban dibagi menjadi dua bagian: wajib mutlak dan muaqqat. Kewajiban mutlak adalah kewajiban yang tidak ditentukan waktu pelaksanaannya. Seperti orang yang bersumpah untuk menjalankan sumpahnya, tetapi melanggar sumpahnya, maka orang tersebut boleh segera membayar denda seketika atau pada waktu lain setelah melanggar sumpahnya. Sedangkan kewajiban muaqqat adalah kewajiban yang telah ditentukan waktu pelaksanaannya. Misal, shalat

${ }^{11}$ Mukhtar Yahya dan Fatchur Rahman, Dasar-Dasar Pembinaan Hukum Fiqh Islami..., 125

12 Mukhtar Yahya dan Fatchur Rahman, Dasar-Dasar Pembinaan Hukum Fiqh Islami...,128-129

${ }^{13}$ Mukhtar Yahya dan Fatchur Rahman, Dasar-Dasar Pembinaan Hukum Fiqh Islami... ,130-133 
lima waktu telah ditentukan masing-masing waktunya, sehingga tidak sah dikerjakan sebelum dan sesudah habis waktunya. Ketentuan tentang kewajiban muaqqat dapat dibagi menjadi tiga kelompok, yaitu: waktu longgar (muwassa') seperti waktu shalat, waktu sempit (mudhayyaq) seperti waktu puasa, serta waktu yang mengandung longgar dan sempit (dzusabihain) seperti waktu haji

2. Pertimbangan berdasarkan ukuran jumlah yang diperlukan secara khusus dan tidak terbatas. Jenis kewajiban ini dapat dibagi menjadi dua, yaitu: wajib yang ditentuntkan jumlahnya(muhaddad), seperti jumlah rakaat shalat, dan kewajiban yang tidak ditentukan jumlahnya (ghair muhaddad) seperti jumlah derma atau infaq.

3. Pertimbangan berdasarkan pasti dan pilihan. Jenis kewajiban ini dibagi menjadi dua macam, yaitu kewajiban yang sudah ditentukan (mu'ayyan) seperti kewajiban menjalankan shalat, puasa, zakat, haji, dan lain-lainnya. Dan yang kedua adalah kewajiban yang boleh dipilih (mukhayyar) seperti orang yang melanggar sumpah dapat memilih salah satu jenis pembayaran tebusan, membayar makanan, memberi pakaian kepada 10 orang fakir miskin, atau memerdekakan budak.

4. Pertimbangan berdasarkan individu dan kelompok mukallaf. Jenis kewajiban ini dapat dibagi menjadi dua, yaitu kewajiban yang dibebankan kepada setiap individu ('aini), seperti shalat, zakat, dan lain-lain; dan kewajiban bagi kelompok orang (kifai), seperti kewajiban mengurus jenazah.

\section{$N a d b$}

$N a d b$ ini merupakan ketentuan syar'i yang menuntut agar seseorang melaksanakan perbuatan yang tidak mesti dijalankan. Implikasi dari ketentuan ini dapat dijalankan secara sukarela yang biasa disebut sebagai sunnat atau mandub. Ulama Madzhab Hanafi juga membedakan kedua jenis ini. Baginya, yang disebut sunnat adalah seluruh perbuatan Rasulullah saw yang selalu dikerjakan kecuali ada halangan. ${ }^{14}$ Sedangkan mandub adalah perbuatan yang lebih banyak ditinggalkan daripada yang dikerjakan. Hukum nadb merupakan jenis hukum yang memiliki konsekuensi pahala (reward) bagi yang menjalankan, namun tidak ada sanksi (punnish) bagi orang yang meninggalkan. Indikator untuk mengetahui bahwa perbuatan tersebut mandub atau sunnat antara lain dapat dilihat pada: ${ }^{15}$

1. Kalimat yang tegas menunjukkan kesunnahannya, seperti kalimat "yusannu" atau "yundabu".

\footnotetext{
14 Mukhtar Yahya dan Fatchur Rahman, Dasar-Dasar Pembinaan Hukum Fiqh Islami..., 125

15 Mukhtar Yahya dan Fatchur Rahman, Dasar-Dasar Pembinaan Hukum Fiqh Islami..., 136
} 
2. Adanya kata kerja perintah ( $f i^{\prime}$ il $a m r$ ) dengan diikuti petunjuk (qarinah) yang mengacu pada pengertian sunnat. Bedanya dengan wajib di sini tidak terdapat ancaman sanksi siksa bagi yang tidak menjalankan.

Mandub atau sunnah dapat dibagi menjadi tiga bagian, yaitu: sunnat muakkad, sunnat zaidah, dan mushtahab. Sunnat muakkad atau hadyi adalah jenis sunnat yang ketika tidak dijalankan mengakibatkan orang tersebut menjadi tercela. Salah satu contoh dari jenis sunnat muakkad adalah melakukan adzan. Sunnat zaidah, atau biasa disebut nafilah atau jenis sunnat yang ketika tidak dijalankan tidak mendapatkan akibat apa-apa, termasuk celaan. Salah satu contoh dari jenis sunnat ini adalah berpuasa Senin-Kamis. Sedangkan jenis sunnat ketiga adalah mushatahabatau fadhilah. Jenis sunnat ini adalah perbuatan yang memberikan kesempurnaan suatu perbuatan dan peningkatan derajat yang lebih daripada umumnya sebagai bukti kecintaan kepada Rasulullah SAW. Dan orangorang yang tidak menjalan hal ini tidak mendapat sanksi apapun. ${ }^{16}$

\section{Tahrim}

Tarhrim ini merupakan ketentuan syar'i yang menuntut agar seseorang meninggalkan perbuatan secara jelas dan tegas. Implikasi dari ketentuan ini disebut hurmah dan perbuatan atau tindakan yang dituntut untuk ditinggalkan disebut sebagai haram atau mahzhur. Ulama Madzhab Hanafi juga membedakan kedua jenis ini. Baginya, yang disebut tahrimadalah yang didasarkan pada dalil qath'i. Adapun yang berdasarkan dalil zhanni disebut sebagai karahah tahrim. ${ }^{17}$ Kebalikan dari hukum wajib, hukum tahrim merupakan jenis hukum yang memiliki konsekuensi pahala (reward) bagi orang yang meninggalkan dan sanksi (punnish) bagi yang menjalankan. Indikator untuk mengetahui hukum tahrim dalam khitab atau ketentuan di antaranya dapat dilihat pada: ${ }^{18}$

1. Terdapat kata-kata yang tegas melarangnya, seperti kata "harrama" dan segala bentuk perubahan katanya.

2. Menggunakan kata kerja larangan (fiil nahi) dan disertai dengan penjelasan bahwa perbuatan tersebut benar-benar dilarang, seperti adanya kata "la taqrabu" ditegaskan dengan kata-kata lain "fakhisyah" atau "sa'a sabilan" dalam surat al-Isra ayat 32 .

3. Perintah untuk menjauhi

4. Adanya ancaman hukuman atau siksa bagi yang menjalankan, seperti anacaman siksa api neraka atau cambuk, dan lain-lain.

\footnotetext{
16 Mukhtar Yahya dan Fatchur Rahman, Dasar-Dasar Pembinaan Hukum Fiqh Islami..., 137

17 Mukhtar Yahya dan Fatchur Rahman, Dasar-Dasar Pembinaan Hukum Fiqh Islami...,126

18 Mukhtar Yahya dan Fatchur Rahman, Dasar-Dasar Pembinaan Hukum Fiqh Islami...,138-139
} 
Jenis hukum haram dapat dibagi menjadi dua, yaitu haram sejak awal ditetapkan (lidzatih) dan haram karena adanya faktor di lain (li 'aridhih atau $l i$ ghairih). Jenis haraam li(bi)dzatih adalah ketentuan keharaman syar'i sejak asalnya karena mengandung bahaya dan bersifat merusak, seperti mencuri, berzinah, dan lain-lain. Sedangkah jenis haram lighairih adalah sesuatu yang tidak ditetapkan keharamannya oleh syar'i sejak awalnya, tetapi karena ada faktor lain yang dapat menyebabkan keharaman perbuatan tersebut. Di antara contoh dari jenis ini adalah haramnya jual-beli dengan adanya unsur penipuan. Jual-beli pada dasarnya adalah tidak haram, namun karena ada unsur penipuan, makan ia menjadi haram. Begitu hukum asal menalak istri, pada awalnya adalah boleh. Namun karena istrinya sedang haidl, maka hukumnya menjadi haram. ${ }^{19}$

\section{Karahah}

Karahah ini merupakan ketentuan syar'i yang menuntut agar seseorang meninggalkan perbuatan dengan tuntutan yang tidak tegas untuk ditinggalkan. Implikasi dari ketentuan ini biasa disebut sebagai makruh. Ulama Madzhab Hanafi jenis hukum ini disebut sebagai karahah-tanzih. ${ }^{20}$ Hukum karahah ini kebalikan dari hukum nadb, di mana memiliki konsekuensi pahala (reward) bagi yang meninggalkan, namun tidak ada sanksi (punnish) bagi orang yang menjalankan. Indikator untuk mengetahui hukum karahah dalam khitab atau ketentuan dalil di antaranya dapat dilihat pada: ${ }^{21}$

1. Kata-kata yang digunakan menunjukkan larangan bersifat makruh, seperti terdapat kata "karaha" "yukrahu" dengan segala bentuk dan perubahan katanya.

2. Menggunakan kata kerja larangan (fiil nahi), namun dalam nash yang lain terdapat penjelasan yang bukan menunjukkan keharamannya.

3. Perintah untuk menjauhi suatu perbuatan dengan adanya qarinah yang menunjukkan perbuatan tersebut makruh.

Jenis hukum makruh dapat dibagi menjadi tiga kelompok, yaitu: makruh tanzih, makruh aula, dan makruh tahrim. Makruh tanzih adalah perbuatan yang lebih baik ditinggalkan daripada dikerjakan. Makruh aula adalah meninggalkan suatu perbuatan yang sebenarnya lebih baik untuk dilaksanakan. Dan makruh tahrim adalah perbuatan yang larang, namun dalil larangannya bersifat zhanni. ${ }^{22}$

\section{Ibahah}

\footnotetext{
19 Mukhtar Yahya dan Fatchur Rahman, Dasar-Dasar Pembinaan Hukum Fiqh Islami..., 140

${ }^{20}$ Mukhtar Yahya dan Fatchur Rahman, Dasar-Dasar Pembinaan Hukum Fiqh Islami..., 127

21 Mukhtar Yahya dan Fatchur Rahman, Dasar-Dasar Pembinaan Hukum Fiqh Islami...,141-142

${ }^{22}$ Mukhtar Yahya dan Fatchur Rahman, Dasar-Dasar Pembinaan Hukum Fiqh Islami..., 143
} 
Ibahah merupakan ketentuan syar'i yang mengandung pilihan bagi orangorang mukallaf untuk menjalankan atau meninggalkan. Implikasi dari ketentuan ini biasa disebut sebagai mubah atau jaiz, atau halal. Jenishukum ibahah ini tidak memiliki konsekuensi pahala (reward) bagi yang menjalankan atau meninggalkan, dan tidak ada sanksi (punnish) pula bagi orang yang menjalankan atau meninggalkan. ${ }^{23}$ Indikator untuk mengetahui hukum karahah dalam khitab atau ketentuan dalil di antaranya dapat dilihat pada: ${ }^{24}$

1. Perbuatan yang ditetapkan secara tegas dan jelas diperbolehkan dalam ketentuan syara. Misal, "la junaha”, "la haraja", "la itsma", dan lain-lain..

2. Ada ketentuan perintah untuk melaksanakan suatu perbuatan, namun terdapat penjelasan (qarinah) yang menunjukkan bahwa perintah tersebut hanya untuk mubah saja.

3. Adanya ketetapan tentang kebolehan melakukan perbuatan yang didasarkan pada hukum asalnya, di mana hukum asal dalam bermuamalat adalah boleh atau mubah.

\section{Ahkam al-Khams dalam Dinamika Pemikiran Hukum Islam dan Perubahan Sosial}

Meski perubahan sosial telah memengaruhi berbagai dimensi hukum, namunAhkam al-Khams tetap bertahan sebagai klasifikasi dan kerangka nalar normatif yang kokoh. Lima kategori hukum yang dirumuskan para ahli Fiqih dan Ushul merupakan standar yang mampu menembus perubahan sosial yang dinamis. Dalam sistem hukum Islam,Ahkam al-Khams adalah persoalan yang mencakup seluruh kehidupan manusia, baik terkait dengan duniawi maupun ukhrawi. Umumnya, ketika terjadi perubahan salah satu dimensi atau aspek kehidupan, akan berimplikasi pada perubahan yang lain. Walaupun aspek-aspek lain mengalami pergolakan pemikiran di antara para ahli dan intelektual, termasuk perkembangan aliran keislaman yang makin beragam, lima kategori tersebut hampir tidak tersentuh. Bahkan ia menjadi acuan hampir semua aliran pemikiran, kecuali Mu'tazilah dan Hanafiyah. Sebagaimana diketahui, perdebatan tentang hukum Islam, baik terkait sumber-sumber maupun pengambilan hukum telah terjadi sejak masa lalu, sehingga terdapat berbagai aliran pemikiran. Menurut Thaha Jabir Fayadh al-'Ulwan, saat ini tidak kurang telah muncul 13 aliran. Ketiga belas aliran tersebut berafiliasi dalam Ahlussunnah. Dari ketiga belas mazhab yang berkembang saat itu terdapat empat mazhab yang masih bertahan

\footnotetext{
23 Mukhtar Yahya dan Fatchur Rahman, Dasar-Dasar Pembinaan Hukum Fiqh Islami..., 125

4 Mukhtar Yahya dan Fatchur Rahman, Dasar-Dasar Pembinaan Hukum Fiqh Islami...,143
} 
dan mendapat legitimasi dari generasi berikutnya. Keempat mazhab dikenal dengan madzahib al-arba'ah: Hanafi, Maliki, Syafi'i dan Hanbali. ${ }^{25}$

Selanjutnya, pada masa kini, kembali muncul beberapa varian pemikiran hukum Islam. Muhammad Harfin Zuhdi menyatakan, aliran yang berkembang saat ini antara lain tradisional, moderat, dan liberal atau revivalis, neo revivalis, modernis, neo modernis. ${ }^{26}$ Aliran pemikiran yang punya kecenderungan pengambilan hukumnya hanya berorientasi pada tekstual tentu saja berbeda dengan aliran yang berorientasi secara kontekstual. Begitu juga terkait implikasi terhadap penemuan-penemuan tafsir baru atas ayat-ayat tertentu, memang berimplikasi terjadinya pergeseran perubahan hukum atas suatu kasus. Begitu juga terkait dengan temuan-temuan ilmiah atas produk-produk tertentu yang bisa mengubah status hukum tertentu. Hal ini menyebabkan dialektika dan perdebatan tentang hukum Islam tidak hanya persoalan yang bersifat cabang, tetapi juga merambah pada hal-hal yang fundamental, yang sebelumnya dianggap telah final. kasus munculnya imam shalat perempuan bagi kaum laki-laki, misalnya, merupakan salah satu contoh kontroversial dalam hukum Islam akibat pendekatan baru yang dipelopori kelompok feminis yang bersebrangan dengan pendapat mayoritas ulama klasik. Kaum feminis mendasarkan kebolehan perempuan menjadi imam shalat atas laki-laki pada sebuah hadis yang diriwayatkan Imam Ahmad dan Sunan Abi Daud, yang berbunyi:

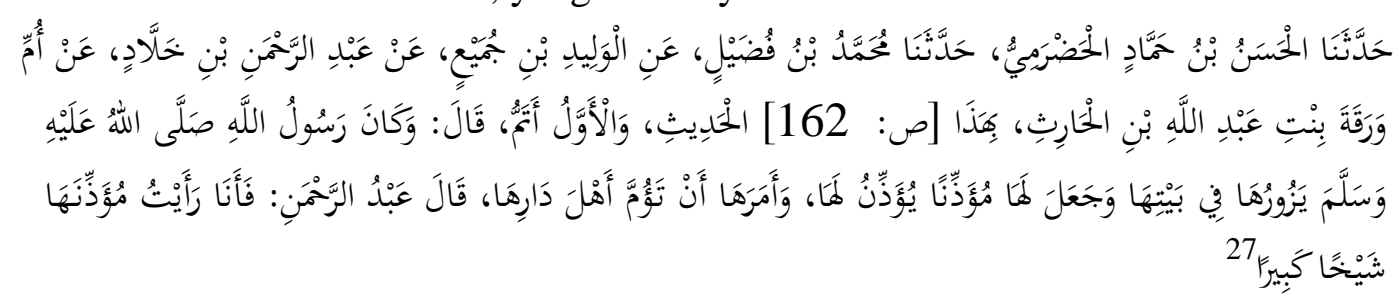

Berdasarkan penjelasan yang dikemukakan al-Shana'ani al-Kahlani, bahwa yang diimami oleh Ummu Waraqah bukan hanya lelaki tua, tetapi juga beberapa hamba sahaya laki-laki. Atas penjelasan tersebut, hal ini dijadikan sebagai hukum kebolehan perempuan mengimami laki-laki, walaupun kebolehan ini cuma berlaku di dalam keluarga sendiri. Dan ketika hal ini kembali mengemuka dalam perdebatan relasi gender dalam hukum Islam, maka apakah kasus seperti ini juga mengubah elemen hukum Islam?. Perkembangan teknologi informasi saat ini juga sangat berkaitan dengan tanggapan hukum Islam. Perubahan teknologi informasi juga melahirkan bentuk-bentuk perbuatan baru,

\footnotetext{
${ }^{25}$ Thâha Jâbir Fayadh al-'Ulwânî, Adâb al-Ikhtilâf, (Washington: The Internationa IInstitute of Islamic Though, 1987), 87-88.

${ }^{26}$ Muhammad Harfin Zuhdi, "Karakteristik Pemikiran Hukum Islam”, (Jurnal Ahkam: Vol. XIV, No. 2, Juli 2014), 173-184

${ }^{27}$ 1-Imâm al-Hâfizh Sulaimân al-Asy’ats al-Sajastânî Abû Dâwud, Sunan AbîDâwud, Juz II, ditahqiq dan dita'liq oleh Muhammad 'Abdul 'Azîz al-Khâlidî, (Beirût:Dâr al-Kutub al'Ilmiyyah, 1996 M/1416 H), Kitâb al-Shalâh Bâb Imâmah al-Nisâ',Hadis ke-500.
} 
seperti chating antara laki-laki dan perempuan. Apakah hal ini juga dipandang sebagai persoalan larangan untuk mendekati perbuatan zina?. Karena itu, diperlukan penafsiran baru atas nash untuk merespon kebutuhan dan tuntutan masyarakat. ${ }^{28}$ Dinamika sosial dan hukum Islam dalam perkembangannya saling memengaruhi perubahan. Menurut Fathurrahman Azhari, perubahan sosial dapat disebabkan adanya hukum Islam. Sejarah risalah Rasulullah saw menunjukkan secara jelas bahwa bangsa Arab jahiliah yang berpegang kepada tradisinya mengalami perubahan drastis karena masuknya hukum Islam. Sebaliknya, perubahanhukum Islam juga dipengaruhi oleh adanya perubahan sosial yang berlaku. Oleh karena itu, berubahnya fatwa akibatnya perubahan masa, tempat, keadaan, dan kebiasaan masyarakat merupakan hal yang alami dan wajar. Dan hal ini menunjukkan bahwa hukum Islam bersifat dinamis dan adaptif terhadap perubahan zaman dan sosial. ${ }^{29}$

Meski dinamika hukum Islam mengalami dinamika, namun standar hukum yang dipergunakan masih tetap. Perkemabngan hukum Islam mengalami dinamika akibat proses ijtihad yang progresif. Sebagaimana dikemukakan Zulkarnain Suleman, ijtihad yang progresif telah melahirkan 4 (empat) produk hukum Islam, yaitu: fiqih, fatwa, qanun, dan putusan peradilan. Dampak selanjutnya adalah munculnya keragaman pendapat (ikhtilaf). Masing-masing madzhab dalam fiqih juga menunjukkan karakteristiknya masing-masing, seperti Hanafi yang cenderung rasional, Hambali cenderung mengemukakan makni lahir hadis, dan Zahiri yang cenderung tekstual. Atas dasar bukti-bukti tersebut, Suleman berargumentasi bahwa hukum Islam bukan produk pemikiran statis, sebaliknya tampak dinamis. ${ }^{30}$ Meski berbagai perkembangan dan dinamika hukum dan sosial berjalan sangat dinamis, para ahli hukum tetap menggunakan kategori hukumhukum yang telah ada tersebut seampai sakarang. Dengan demikian, hingga saat ini tidak terdapat temuan baru selain lima kategori hukum tersebut, kecuali sekadar pergeseran dari boleh menjadi haram, atau dari haram menjadi boleh, atau lainnya. Kekokohan ajaran Ahkam al-Khams terhadap perubahan zaman dan sosial justru memberikan pedoman dalam berbagai bidang untuk mencapai kebaikan bersama. Dalam pandangan teori perintah ketuhanan, sebagaimana dikemukakan Jawed Akhtar Mohmmed, menunjukkan bahwa etika bisnis yang diatur berdasarkan gagasan halal dan haram sebagaimana dalam ajaran Ahkam alKhams, justru dapat menunjukkan tanggung jawab sosial dan kesepakatan secara

\footnotetext{
${ }^{28}$ Laila Mulasari, "Kebijakan Formulasi tentang Tindak Pidana Kesusilaan di Dunia Maya dalam Perspektif Hukum Islam”, dalam Jurnal Masalah-Masalah Hukum, jilid 41 Nomor 1 Januari 2012, 98-109

${ }^{29}$ Fathurrahman Azhari, "Dinamika Perubahan Sosial dan Hukum Islam", (Jurnal AlTahrir, Vol. 16, No. 1 Mei 2016), 197 - 221

${ }^{30}$ Zulkarnain Suleman, "Dinamika Pemikiran Hukum Islam: Corak dan Karakteristik", (Jurnal Al-Mizan Volume 12 Nomor 1 Juni, 2016)
} 
adil. Motif operasi bisnis bagi muslim tidak hanya bermanfaat bagi keuntungan, tetapi juga lingkungan dan tanggung jawab sosial. ${ }^{31}$

\section{Penutup}

Ahkam al-Khams sebagai standar atau kategori dan klasifikasi hukum dalam Islam merupakan penilaian mengenai benda dan tindakan atau perilaku mukallaf yang didasarkan pada ketentuan pembuat hukum.Ahkam al-Khams terdiri atas lima kategori, yaitu: Wajib, Mandub, Mubah, Makruh, dan Haram. Kelima hukum tersebut menjadi acuan untuk menilai perilaku atau tindakan ( $\mathrm{amal}$ ) para mukallaf, baik terkait berhubungan dengan Tuhan (ibadah) maupun hubungan sesama manusia (muamalah). Ketetapan-ketetapan hukum tersebut pada dasarnya bersumber pada wahyu, yang diinterpretasikan para ulama berdasarkan pada kondisi dan kriteria tertentu, ada yang bersifat jelas dan pasti (qath'i) serta ada yang bersifat keras (dzanny). Meski perdebatan tentang hukum Islam mengalami dinamika, namun standar hukum yang dipergunakan masih tidak bergeser dari yang lima tersebut. Hal ini, menunjukkan bahwa perubahan sosial dan dinamika pemikiran hukum Islam turut memengaruhi berbagai dimensi hukum, namun demikian Ahkam al-Khams sebagai klasifikasi dan kerangka nalar normatif tetap bertahan dan kokoh dari berbagai perubahan yang ada hingga saat ini.

\section{DAFTAR PUSTAKA}

Abu Abdullah, Syarh al-Mukhtashar li Nazhm al-Waraqat

Ali, Zainuddin. Hukum Islam : Pengantar Ilmu Hukum Islam di Indonesia. Jakarta : Sinar Grafika, 2010.

Azhari,Fathurrahman. "Dinamika Perubahan Sosial dan Hukum Islam”, dalam A1Tahrir, Vol. 16, No. 1 Mei 2016.

Azhary,M. Tahir. Bunga Rampai Hukum Islam : Sebuah Tulisan. Jakarta : Ind HillCo, 2003.

Dawud,al-Imam al-Hafizh Sulaimân al-Asy'ats al-Sajastani Abu, Sunan Abî Dâwud, Juz II, ditahqiq dan dita'liq oleh Muhammad 'Abdul 'Azîz alKhâlidî, (Beirût: Dâr al-Kutub al-'Ilmiyyah, 1996 M/1416 H), Kitâb alShalâh Bâb Imâmah al-Nisâ', Hadis ke-500.

Mazighah, Aminah. al-Manhaj al-Ijtihad 'Ind Hujjah al-Islam Abi Hamid alGhazaly. Dar al-Kutub al-Ilmiyah, 2019.

Mohmmed,Jawed Akhtar. "The Ethical System in Islam Implications for Business Practices", dalam C. Luetge (ed.), Handbook of the Philosophical Foundations of Business Ethics,. Springer, 2013.

\footnotetext{
${ }^{31}$ Jawed Akhtar Mohmmed, "The Ethical System in Islam-Implications for Business Practices", dalam C. Luetge (ed.), Handbook of the Philosophical Foundations of Business Ethics, (Springer, 2013), h.873-882 DOI 10.1007/978-94-007-1494-6_3,
} 
Mughal, Munir Ahmad. Islamic Jurisprudence (August 2, 2000). http://dx.doi.org/10.2139/ssrn.1903980

Mulasari, Laila. "Kebijakan Formulasi tentang Tindak Pidana Kesusilaan di Dunia Maya dalam Perspektif Hukum Islam", dalam Jurnal Masalah-Masalah Hukum, jilid 41Nomor 1 Januari 2012.

Nasution, Muhammad Syukri Albani, Filsafat Hukum Islam. Jakarta: Rajawali Pers, 2014.

Sulaiman, Abu Daud. Sunan Abu Daud juz 3, Hadist nomor 3592. Beirut: Maktabah al-Ashriyah.

Suleman, Zulkarnain. "Dinamika Pemikiran Hukum Islam: Corak dan Karakteristik", dalam Jurnal Al-Mizan Volume 12 Nomor 1 Juni, 2016.

Ulwani. Thaha Jabir Fayadh al-`, Adâb al-Ikhtilaf. Washington: The International Institute of Islamic Though, 1987.

Yahya. Mukhtar dan Fatchur Rahman, Dasar-Dasar Pembinaan Hukum Fiqh Islami. Bandung: Al-Ma'arif, 1986.

Zuhdi, Muhammad Harfin. "Karakteristik Pemikiran Hukum Islam", dalam Ahkam: Vol. XIV, No. 2, Juli 2014. 